\title{
Determinants of Agricultural Technology Adoption: The Case of Improved Highland Maize Varieties in Toke Kutaye District, Oromia Regional State, Ethiopia
}

\author{
Dawit Milkias ${ }^{1}$, Abduselam Abdulahi, ${ }^{2, *}$ \\ ${ }^{1}$ Department of Agricultural Economics Research, Ethiopian Institute of Agricultural Research, Ambo, Ethiopia \\ ${ }^{2}$ Department of Agricultural Economics, Kebridehar University, Kebridehar, Ethiopia \\ Email address: \\ Mkdave04@gmail.com (D. Milkias), Abdisalan654@gmail.com (A. Abdulahi) \\ ${ }^{*}$ Corresponding author
}

To cite this article:

Dawit Milkias, Abduselam Abdulahi. Determinants of Agricultural Technology Adoption: The Case of Improved Highland Maize Varieties in Toke Kutaye District, Oromia Regional State, Ethiopia. Journal of Investment and Management. Vol. 7, No. 4, 2018 , pp. 125-132. doi: $10.11648 /$ j.jim. 20180704.13

Received: June 24, 2018; Accepted: September 6, 2018; Published: October 9, 2018

\begin{abstract}
Improved highland Maize is a new and promising crop gradually becoming important in Ethiopian highlands. Its production is rapidly increasing where it has been a minor crop in the past. The empirical evidences on the determinants of agricultural technology adoption and their intensity of adoption are very limited. In this paper, determinants of adoption and intensity of adoption of improved highland maize varieties were investigated by using descriptive statistics and econometric model (Tobit). Two stage sampling procedure was followed in order to draw 150 sample respondents. The model result revealed that variables such as farm size, household income, access to credit, contact with extension agents, participation in training, and field day were positively and significantly influenced whereas, age of household and market distance negatively influenced adoption and intensity of use of improved highland maize varieties in the study area. Therefore, government policies and intervention on adoption and intensity use of agricultural technology should pay attention and move along with those variables significantly influencing adoption and intensity of use of new agricultural technology.
\end{abstract}

Keywords: Adoption, Intensity, Highland Maize, Agricultural Technology, Tobit Model, Ethiopia

\section{Introduction}

\subsection{Background of the Study}

Maize is the most widely grown and consumed staple crop in Africa with more than 300 million Africans depending on it as their main food source. It is the staple food for 24 million households in east and southern Africa and is annually planted over an area of 15.5 million hectares. Research in to maize improvement practices to optimize grain yields is a priority for governments in the region because of the critical role the crop plays in ensuring food security [2].

In Ethiopia's economy Agriculture continues to be the dominant sector, accounting for 51\% of the GDP in 2009 [20]. Within agriculture, cereals play a central role accounting for roughly $60 \%$ of rural employment, $80 \%$ of total cultivated land. Among cereals, maize is the most important crop in terms of production and contributes significantly to the economic and social development of Ethiopia [5]. In the country out of the major cereal crops, maize ranks second to teff in area and first in production and per capita consumption of maize is $60 \mathrm{~kg} /$ year, Ethiopia. Therefore, highland improved maize production is crucial for Ethiopian people in the short and medium term food security, and as well as for GTP growth [13].

Although a substantial quantity of maize is produced in the lowland areas, predominantly maize is grown in the most productive agricultural lands in the mid and highland areas of the country [6]. The high altitude, sub-humid maize agroecology (1800-2400 m.a.s.l) in Ethiopia is estimated to cover $20 \%$ of the land devoted to annual maize cultivation. More than $30 \%$ of small-scale farmers in this agro-ecology depend on maize production for their livelihoods [18]. To meet the 
needs of increasing maize production in the highlands of the country, the Highland Maize Breeding Program was established at the Ambo Plant Protection Research Center (APPRC) of the Ethiopian Institute of Agricultural Research (EIAR) with the support of the International Maize and Wheat Improvement Center (CIMMYT), in 1998.

It is aimed at developing and popularizing improved Highland maize cultivars, and enhancing their crop management technological packages. From 1999 to 2011, the breeding program released five superior Highland maize hybrids including: AMB02SYN1-'Hora', AMH800'Arganne', AMH850-'Wenchi', AMH851-'Jibat', and MH760Q-'Webi', for large-scale production [6]. AMH760Q was identified as quality protein maize (QPM) hybrid, which was developed from the most popular, top-yielding non-QPM hybrid 'BH660'. Over 5.8 million hectares of potential suitable land was identified for the highland maize hybrids in the country " $[7,8])$ ".

Toke kutaye district have a major potential in highland maize varieties production. The land use pattern of the district shows that 37,509 ha is cultivated land but improved highland maize has not been adopted by farmers. Therefore, this study was intended to identify factors influencing adoption and intensity of use of improved highland maize varieties.

\subsection{Statement of the Problem}

Maize plays a major role in the livelihood and food security of most smallholder farmers in Sub-Saharan African countries including Ethiopia. Maize is grown in most parts of the country with different agro-ecological suitability and productivity potentials. Data from [5] shows that, during the 2009/10 production year, Ethiopia produced 3.89 million tons of maize on 1.77 million ha of land.

High land maize is one of the major food crops where research brought tangible improvement in production and productivity. However, in sub-humid agro-ecology, smallholder farmers' knowledge and use of agricultural technologies in general and improved highland maize varieties in particular, are limited " $[18,6]$ ". In the study area, the highlands hybrids maize has not been violently accepted, and not adopted by farmers this is why the current study aimed in identifying factors that influence adoption and intensity of use of improved highland maize varieties and exploring farmers' perception towards this technology in the study area.

\subsection{Objectives of the Study}

\subsubsection{General Objective}

The overall objective of this study is to assess factors influencing intensity of adoption of improved Highland maize varieties in the selected kebeles of Toke kutaye district

\subsubsection{Specific Objectives}

(1) To analyze intensity use determinants of improved highland maize varieties in the study area
(2) To provide policy recommendation towards improved highland maize varieties

\section{Empirical Studies on the Adoption of Agricultural Technologies}

Adoption of new agricultural technology has attracted the attention of development economists and policy makers nowadays since it is believed that introduction of new technology increases production and productivity and technology transfer helps to achieve economic growth for economic developing countries [9]. Analysis of intensity adoption for new technology require careful evaluation of a large number of technical, political and socio-economic factors to identify determinants of whether and when farmers adoption decision takes place.

The history and economics of diffusion and adoption of agricultural technologies began in the mid-age of 1957 where the process and models of adoption have been studied by different scholars, with the most popular and widely used being that of Everett Rogers, titled diffusion of innovations [17], which spans the disciplines of economics, technology, education, political science, public health, history and communications.

In the literature, technology and innovation are sometimes used interchangeably. While the process by which a new technology or innovation is transmitted through certain media over time to members of society is referred to as diffusion, the rate at which a new or emerging technology is adopted depends on some important attributes of the technology including the perceived advantages relative to existing ones and its compatibility with existing needs and values of the society or potential adopter, simplicity (ease of understanding and use), trial ability for potential adjustment, and observability [16].

Adoption of improved agricultural technologies has been traced to the success of the Green Revolution initiated by an American scientist, Norman Borlaug, in Mexico in the 1940s [7]. The Green Revolution enhanced the adoption of highyielding crop cultivars and inputs such as fertilizer and irrigation, which resulted in increased food production [13]. Improved high-yielding crop varieties developed during the revolution produced high yields with the help of fertilizers and irrigation systems, which provide water for farming in areas with little or no rainfall, thereby putting more land to use for food production [4] Results of some empirical studies [12] underscore the potential of improved agricultural technologies in enhancing productivity, income, and overall economic growth.

The potential benefits of a new technology can only be realized when it is adopted and used; the adoption decision involves a critical comparison of perceived benefits and costs associated with the technology [19]. A better understanding of the diffusion, adoption, and impact of improved technologies will guide producer groups, research institutions, and policy makers in making prudent and 
informed decisions about allocating resources for technology development.

Some studies that examine agricultural new technology adoption and level of adoption intensity have been carried out, particularly in developing countries like that of [14]. Different Scholars used different econometric models to examine adoption and intensity use of agricultural technology, example [1] used probit and random effect models to examine the influence of farmer learning and risk on the likelihood and intensity of adopting improved teff and wheat technologies in northern and western Showa zones of Ethiopia. The study underscores the importance of learning and experience as drivers of continued technology adoption. Results indicate that awareness, timely availability, and profitability of new teff and wheat varieties enhanced farmers' learning and experience. This positively influenced adoption of the new technologies.

[7] employed an average treatment estimation (ATE) framework to examine the adoption rate and determinants of adoption of new rice variety for Africa (NERICA) in Gambia. Results of the study show that the adoption rate stood at $40 \%$ against anticipated rate of $83 \%$ due to lack of information about and access to NERICA, thereby suggesting the need for the supply and distribution of more NERICA to farmers for easy access, experience, and adoption. In another study carried out in Africa, [19] looked at the factors influencing agricultural technology adoption by rural households in Mozambique.

Attended a higher level of education, and are members of agricultural associations have a higher probability of adopting new agricultural technologies. Learning through networks has been identified as a factor that influences technology adoption. For example, [3] examined the role of social networks and how the adoption choices of network members influence a farmer's adoption decision in Northern Mozambique. They found that farmers who discuss and/or learn about new technologies within their social network have a greater tendency to adopt. However, this result cannot be generalized.

As stated earlier, the technical opinion of social network leaders on a particular technology affects adoption by members of the social network. If the leader's opinion is not in favour of the new technology, members may not adopt. [21]used an extension service is an important component of adoption that motivates potential adopters to be profitable. [15] estimated the time and costs involved in the process of developing a new plant biotechnology from discovery to authorization by regulatory authorities, fuelling the debate as to whether the time and costs associated with the development of a new technology. Technological advancement and adoption are relevant for improvements in every sector.

In recent years, there has been an increase in funding for agricultural research and development in technological innovations, particularly by the private sector. This has yielded positive returns on investment. However, significant adoption and commercialization of emerging technologies has not been achieved, particularly in lessdeveloped countries, due to a combination of cultural beliefs, ethical concerns, regulatory delays, and lack of information and understanding of the science and technology being used. This has put consumers and producers in a dilemma. Although significant improvements have been made in technological advancement, more is needed to better understand the root causes of low adoption rates, especially in developing countries [15].

\section{Methodology}

\subsection{Description of the Study Area}

The study was conducted in Toke Kutaye district which is located about $128 \mathrm{~km}$ west of Capital city of EthiopiaAddis Ababa and $12 \mathrm{~km}$ west direction of Ambo Town. Geographically, the district lies between $8^{0} 47^{\prime}$ to $9^{0} 21$ latitudes and $37^{0} 32$ to $37^{0} 03^{\prime} \mathrm{E}$ longitude. The district has meant annual rainfall of $1100 \mathrm{~mm}$ with annual mean temperature of $19.5^{\circ} \mathrm{C}$, the main rainy season of the district is from May to September and elevation ranging from 1500 to $2000 \mathrm{~m}$ above mean sea level.

Administratively, the district made up of 24 kebeles (20 rural and 4 urban kebeles). The total population number of the study area is 134,767 (66,492 males and 68,275 female). There are 22,895 household head farmers on average land size of $788.87 \mathrm{~km}^{2}$. The land use pattern of the district shows that 37,509 ha is cultivated land; 3651 ha is covered with forest, 11,603ha is grazing land and 26,124 ha with bush and shrubs. The major crops produced in the district are Teff, Maize, wheat, Sorghum and barley.

\subsection{Sampling Procedure and Sample Size Determination}

Two stage sampling techniques were employed to select the sample respondents. First stage was purposive selection of highland maize growing Kebeles of the districts, followed by selection of sample households. The Kebele identification was made through reviewing secondary data on production potential of maize and dissemination of the improved highland maize technologies and area coverage of the crop. In the second stage 150 sample respondents were chosen using systematic random sampling technique from each kebeles based on probability proportional to size through using the following formula of sample determination:

$$
\begin{aligned}
& \mathrm{n}=\mathrm{N} / 1+\mathrm{N}(\mathrm{E})^{2} \\
& \mathrm{n}=3954 / 1+3954(0.08)=150
\end{aligned}
$$

Where $\mathrm{n}$ is the sample size for the study, $\mathrm{N}$ is the total households of the study area which is 3954 , e is the maximum variability or margin of error or which is 0.08 in this study, 1 is the probability of the event occurring. The sample size from each kebeles' was determined based on their proportion to total share of households residing in each kebeles. 
Table 1. Sample size termination.

\begin{tabular}{llll}
\hline No. & Sample kebeles & Households & Sample size \\
\hline 1 & Kolba anchabi & 550 & 21 \\
2 & Maruf & 1031 & 39 \\
3 & Dadagalan & 1123 & 43 \\
4 & Imala Dawo Ajo & 1250 & 47 \\
& Total & 3954 & 150 \\
\hline
\end{tabular}

Source: Author's compilation, 2017.

\subsection{EconometricModel Specification}

Tobit model is an extension of the probit model and it is really one approach to dealing with the problem of censored data. This model was chosen because; it has an advantage over other analytical models in that, it reveals both the probability of adoption and intensity of use of the technology [10].So, Tobit model is more appropriate to give reliable output of both discrete and continuous variable combination.

The Tobit model "[11, 10]", which tests factors affecting adoption and intensity of adoption improved highland maize varieties production, can be specified as follows:

$$
\begin{gathered}
\mathrm{Y}^{*}=\beta_{0}+\beta \mathrm{ixi}+\mathrm{Ui} \\
\mathrm{Y}=\mathrm{Y}^{*} \text { if } \beta_{0}+\beta \mathrm{ixi}+\mathrm{Ui}>0 \\
\mathrm{Y}_{\mathrm{i}}=0 \text { if } \beta_{0}+\beta \mathrm{ixi}+\mathrm{Ui}<0
\end{gathered}
$$

Where,

$\mathrm{Yi}=$ the observed dependent variable

$\mathrm{Y}^{*}=$ latent variable (which is not observable)

$\mathrm{X} \mathrm{i}=$ Vector of explanatory variable

$\beta=$ vector of parameters to be estimated

$\mathrm{Ui}=$ an independent normally distributed error term with zero mean and constant variance

The model parameters are estimated by maximizing the Tobit likelihood function of the following form [11].

$$
L=\prod_{Y_{i}^{*} \succ 0} \frac{1}{\sigma} f\left(\frac{Y_{i}-\beta_{i} X_{i}}{\sigma}\right) \prod_{Y_{i}^{*} \leq 0} F\left(\frac{-\beta_{i} X_{i}}{\sigma}\right)
$$

Where $\mathrm{f}$ and $\mathrm{F}$ are respectively, the density function and

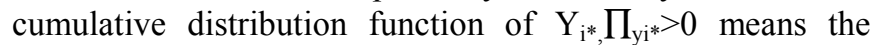
product over those $\mathrm{i}$ for which $\mathrm{y}_{\mathrm{i}^{*}}>0$, and $\prod_{\mathrm{i}^{*}} \leq 0$ means the product over those $\mathrm{i}$ for which $\mathrm{y}_{\mathrm{i}^{*}} \leq 0$.

The interpretation of Tobit model coefficients is the same with that of uncensored linear model coefficients. The significant variables do not all have the same impact on the adoption of improved high land maize varieties. Hence, one has to compute the derivatives of the estimated Tobit model to predict the effects of changes in the explanatory variables. That is probability and intensity of the adoption of improved maize seed. As cited in "[10, 11]" proposed the following techniques to decompose the effects of explanatory variables into adoption and intensity effects.

Thus; change in $\mathrm{Xi}$ (explanatory variables) has two effects. It affects the conditional mean of Yi in the positive part of the distribution, and it affects the probability that the observation will fall in that part of the distribution. Similarly, in this study, the marginal effect of explanatory variables will be estimated as follows. This procedure was used in this study,

(1) The marginal effect of an explanatory variable on the expected value of the dependent variable is:

$$
\frac{\partial E\left(Y_{i}\right)}{\partial\left(X_{i}\right)}=F(z) \beta_{i}
$$

Where, $\frac{\beta_{i} X_{i}}{\sigma}$ is donated by $Z$, the Change in the probability of adopting a technology as independent variable $\mathrm{Xi}$ change is:

$$
\frac{\partial F(z)}{\partial X_{i}}=f(z) \frac{\beta_{i}}{\sigma}
$$

(2) The change in the intensity of adoption with respect to a change in an explanatory variable among adopters is estimated by:

$$
\frac{\partial E\left(Y_{i} / Y_{i}^{*} \succ 0\right)}{\partial X_{i}}=\beta_{i}\left[1-Z \frac{f(z)}{F(z)}-\left(\frac{f(z)}{F(z)}\right)^{2}\right]
$$

Where,

$\mathrm{F}(\mathrm{z})$ is the cumulative normal distribution of $\mathrm{Z}, f(\mathrm{z})$ is the value of the derivative of the normal curve at a given point (i.e., unit normal density), $\mathrm{Z}$ is the $\mathrm{z}$-score for the area under normal curve, is a vector of Tobit maximum likelihood estimates and $\sigma$ is the standard error of the error term. Using descriptive statistics it is also possible to clearly compare and contrast different characteristics of the sample households along with the econometric model.

\subsection{Hypothesis and Definition of Variables}

Dependent variables

The dependent variable used in the Tobit model was adoption of improved highland maize varieties and intensity of adoption which is treated as a continuous variable. It is the amount of improved highland maize varieties that the farmer used whichis measured in Kilogram.

Table 2. Hypothesis and Descriptions of the Variables.

\begin{tabular}{lllll}
\hline Variables & Symbols & Unit & Sign & Descriptions of the Variables \\
\hline Age of HHHs & AGEHH & Years & - & Number of years \\
Education level & EDULEVEL & Years & + & Schooling years \\
Farm Income & INCHH & Birr & + & ETB \\
Credit accessibility & CREDIT & Dummy & + & Dummy: $1=$ if access credit; $0=$ otherwise \\
Extension Contact & CONTEXA & Dummy & + & Dummy: $1=$ if frequency of extension contact; $0=$ otherwise \\
\hline
\end{tabular}




\begin{tabular}{lllll}
\hline Variables & Symbols & Unit & Sign & Descriptions of the Variables \\
\hline Field Day & PARTIFIDA & Number & + & Dummy: $1=$ if yes; $0=$ otherwise \\
Training & PARTRAI & Number & + & Dummy: $1=$ if yes; $0=$ otherwise \\
Labor availability & FAMILAB & Man equi. & + & Man equivalent \\
Market distance & MARKDIST & Kilometer & - & Kilometer \\
Livestock & LIVESHLG & TLU & + & TLU \\
Cosmopolitan & COSMOP & Dummy & + & Dummy: $1=$ if yes; $0=$ otherwise \\
Farm size & FARMSIZ & Hectare & + & Hectare \\
Social organization & PARTORG & Dummy & + & Dummy: $1=$ if yes; $0=$ otherwise \\
\hline
\end{tabular}

Source: Author's compilation, 2017.

\section{Results and Discussions}

\subsection{Results of Descriptive Statistics}

In this study, a total of 13 explanatory variables were identified and out of these variables 9 of them revealed significant association with the adoption and intensity of use of improved highland maize varieties. Variables such frequency of contact with extension agents, access to credit service, social organization, participation in training, Field day and cosmopolitans are dummy, whereas age of household, farm income and farm size are continuous variables that show statistically significant at $1 \%$ and $5 \%$ significant level with the adoption decision. Differently, education level, livestock holding, market distance and labour availability, had not statistically significant relation with the adoption decision. Summary of the overall descriptive results of this study is presented in table 3 and 4 below.

Table 3. Results of Descriptive Statistics for Continuous Variables.

\begin{tabular}{|c|c|c|c|c|c|c|}
\hline \multirow{3}{*}{ Variables } & \multirow{2}{*}{\multicolumn{2}{|c|}{$\begin{array}{l}\text { Adopters } \\
(\mathrm{N}=104) \\
\end{array}$}} & \multirow{2}{*}{\multicolumn{2}{|c|}{$\begin{array}{l}\text { Non-adopters } \\
(\mathrm{N}=46)\end{array}$}} & \multirow{3}{*}{ t-value } & \multirow{3}{*}{ P-value } \\
\hline & & & & & & \\
\hline & Mean & Standard deviation & Mean & Standard deviation & & \\
\hline Age of $\mathrm{HH}$ & 46.89 & 9.57 & 54.17 & 8.43 & 4.45 & $0.00 * * *$ \\
\hline Education level & 1.98 & 0.87 & 2.04 & 0.81 & 0.41 & 0.67 \\
\hline Farm size & 1.12 & 0.221 & 1.206 & 0.23 & 2.08 & $0.04 * *$ \\
\hline TLU & 6.28 & 2.884 & 6.5 & 3.07 & 0.37 & 0.7 \\
\hline Labor & 4.87 & 1.3045 & 5.009 & 1.13 & 0.61 & 0.55 \\
\hline Market distance & 2.44 & 1.01 & 2.4 & 1.0 & -0.16 & 0.87 \\
\hline
\end{tabular}

Source: own survey data, $2017 . * * *, * *$, Significant at 1 and $5 \%$ probability level respectively

Table 4. Resultsof descriptive statistics for Dummy Variables.

\begin{tabular}{|c|c|c|c|c|c|c|}
\hline \multirow{3}{*}{ Variables response } & \multirow{2}{*}{\multicolumn{2}{|c|}{$\begin{array}{l}\text { Adopters } \\
(\mathrm{N}=104)\end{array}$}} & \multirow{2}{*}{\multicolumn{2}{|c|}{$\begin{array}{l}\text { Non-adopters } \\
(\mathrm{N}=46)\end{array}$}} & \multirow{3}{*}{$X^{2}$-value } & \multirow{3}{*}{ P -value } \\
\hline & & & & & & \\
\hline & Frequency & Percent & Frequency & Percent & & \\
\hline \multicolumn{7}{|l|}{ Credit availability } \\
\hline Yes & 91 & 87.5 & 4 & 8.7 & \multirow[t]{2}{*}{$85.3 * * *$} & \multirow[t]{2}{*}{0.000} \\
\hline No & 13 & 12.5 & 42 & 91.3 & & \\
\hline \multicolumn{7}{|l|}{ Social Organization } \\
\hline Yes & 38 & 36.54 & 42 & 91.3 & \multirow[t]{2}{*}{$38.43 * * *$} & \multirow[t]{2}{*}{0.000} \\
\hline No & 66 & 63.46 & 4 & 8.7 & & \\
\hline \multicolumn{7}{|l|}{ Access to Extension } \\
\hline Yes & 103 & 99.04 & 24 & 52.2 & \multirow[t]{2}{*}{$60.23 * * *$} & \multirow[t]{2}{*}{0.000} \\
\hline No & 1 & 0.96 & 22 & 47.83 & & \\
\hline \multicolumn{7}{|c|}{ Participation in Training } \\
\hline Yes & 33 & 31.73 & 1 & 2.17 & \multirow[t]{2}{*}{$15.86^{* * *}$} & \multirow[t]{2}{*}{0.000} \\
\hline No & 71 & 68.27 & 45 & 97.83 & & \\
\hline \multicolumn{7}{|c|}{ Participation in Field day } \\
\hline Yes & 83 & 79.81 & 15 & 32.61 & \multirow[t]{2}{*}{$31.37 * * *$} & \multirow[t]{2}{*}{0.000} \\
\hline No & 21 & 20.19 & 31 & 67.39 & & \\
\hline \multicolumn{7}{|l|}{ Cosmopolitans } \\
\hline Frequently & 46 & 44.23 & 45 & 97.83 & \multirow[t]{2}{*}{$38.39 * * *$} & \multirow[t]{2}{*}{0.00} \\
\hline Not frequently & 58 & 55.77 & 1 & 2.17 & & \\
\hline
\end{tabular}

Source: own survey data, 2017. $* * *$ Significant at $<1 \%$ probability level respectively 


\subsection{Econometric Model Results}

An econometric (Tobit) model was used to determine the influence of various personal, demographic, socio-economic, institutional and psychological variables on adoption and intensity of use of improved highland maize production varieties.

The estimates of parameters of the variables expected to influence adoption of improved highland maize varieties are displayed on Table 5. Thirteen explanatory variables of which 6 are dummy and 7 variables are continuous were taken to the model for analysis. The impact of these variables on the dependent variable is discussed below.

Age: found to be significant at 5 percent level with negative relationship. A year increase in the age of the respondent reduces probability of adoption and intensity of use by 0.7 percent. This implies that the older the respondent, the lower the probability of adoption.

Farm Size: had statistically significant influence at 1 percent level on adoption and intensity of use of improved highland maize varieties which means that an increase in farm size by 1 ha increases the probability and intensity of use of improved highland maize by 4.03 percent; that implies household with larger land holdings allocated more land to improved highland maize varieties production.

Market distance: found to be negatively and significantly associated with the probability of adoption and intensity of use of improved highland maize technology at less than 5 percent. The result indicates that, as the house of the farmer is far by kilometer from main market, the probability of adoption and intensity of use of highland maize varieties decreases by 0.5 percent. The implication of this negative relationship is that if the distance between farmers' living home and the market area is longer, the farmers will be discouraged from adopting improved highland maize varieties.

Contact with extension agents: found to be positive and statistically significant variable in determining adoption and intensity of use at 5 percent level which implies an increase in contact with extension agent increases probability and intensity of adoption of IHM varieties production by 2.8 percent. This is due to the fact that, frequency of contacts with extension agents increases the probability of acquiring up-to-date information on the new agricultural technologies.

Access to credit Services: found to bepositive and significant influence on the likelihood of adoption and intensity of use of improved highland maize technology at 1 percent significance level. The results computed indicated that increase having access to credit by 1 percent increases the probability of adoption and intensity of use of improved highland maize varieties by 3.98 percent respectively. This is due to the fact that access to credit service commands the farmers' financial resources to buy inputs for improved highland maize production. With the availability of credit a household can purchase improved seed and hire extra labour.

Participation in Farmers' Field day: is positively and significantly related to adoption and intensity of use of improved highland maize production technology at 1 percent level of significance. A marginal change in number of participation in field day visits increases probability of adoption and intensity of adoption of improved highland maize by 2.4 percent. Field day is an important method of extension to pull farmers in accepting technologies.

Participation in Training: is positively and significantly related to adoption and intensity of use of improved highland maize variety at 1 percent significant level. The marginal effect result indicates that an increase in participating training by 1 percent increases the probability of adoption and intensity of use of the varieties production 2.8 percent respectively which implies farmers who participate in training will be more likely to adopt new technology than otherwise.

Generally, the model results of this study revealed that a unit increase in explanatory variable will bring certain percent of change or increase on the probability and intensity of adoption of improved highland maize production. Therefore, the current government intervention has to give more emphasis to work on improving the affecting factors of improved highland maize production.

Table 5. Maximum Likelihood Estimates of Tobit Model.

\begin{tabular}{|c|c|c|c|c|c|}
\hline \multicolumn{6}{|c|}{ Number of observation $=150$} \\
\hline \multirow{3}{*}{ Log likelihood $=-257.12$} & & \multirow{2}{*}{\multicolumn{4}{|c|}{$\begin{array}{l}\text { Prob }>\text { chi } 2=0.000 \\
\text { LR chi2 }(13)=208.42\end{array}$}} \\
\hline & & & & & \\
\hline & & \multicolumn{4}{|c|}{ Pseudo R2=0.2884 } \\
\hline \multirow[b]{2}{*}{ Variables } & \multirow[b]{2}{*}{ Estimated Coef. } & \multirow[b]{2}{*}{ Std. Err. } & \multirow[b]{2}{*}{ t-ratio } & \multirow[b]{2}{*}{ P-Value } & Change in probability \\
\hline & & & & & $\frac{\partial F(z)}{\partial X_{i}} \approx f(z) \frac{\beta_{i}}{\sigma}$ \\
\hline Constant & -7.534188 & 2.853968 & -2.64 & 0.009 & \\
\hline AGEHH & -0.075828 & 0.0294787 & -2.57 & $0.01 * *$ & -0.667928 \\
\hline EDULEVEL & 0.287353 & 0.3148265 & 0.91 & 0.363 & 0.2531131 \\
\hline FARMSIZ & 4.583338 & 1.186035 & 3.86 & $0.00 * * *$ & 4.037192 \\
\hline TLU & -0.06053 & 0.0987964 & -0.65 & 0.519 & -0.0533172 \\
\hline INCHH & 0.000326 & $8.69 \mathrm{E}-05$ & 3.75 & $0.00 * * *$ & 0.0002872 \\
\hline LABOR & -0.16429 & 0.2214025 & -0.74 & 0.459 & -0.144722 \\
\hline PARTORG & 0.19413 & 0.6289705 & 0.31 & 0.758 & 0.1708918 \\
\hline MARKDIST & -0.55405 & 0.2463733 & -2.25 & $0.026 * *$ & -0.488026 \\
\hline CONTEXTA & 3.78084 & 1.638886 & 2.31 & $0.023 * *$ & 2.778958 \\
\hline CREDIT & 5.07123 & 0.8379452 & 6.05 & $0.00 * * *$ & 3.976482 \\
\hline PARTIFID & 2.8556 & 0.6473491 & 4.41 & $0.00 * * *$ & 2.372887 \\
\hline
\end{tabular}




\begin{tabular}{|c|c|c|c|c|c|}
\hline & & Number 0 & $=150$ & & \\
\hline Lo likolibod- 25712 & & Prob $>$ chi2 & & & \\
\hline Log ikennood=-25/.12 & & LR chi2(1) & & & \\
\hline & & Pseudo R2 & & & \\
\hline & & & & & Change in probability \\
\hline Variables & Estimated Coef. & Std. Err. & t-ratio & P-Value & $\frac{\partial F(z)}{\partial X_{i}} \approx f(z) \frac{\beta_{i}}{\sigma}$ \\
\hline PARTRAI & 3.04901 & 0.6610033 & 4.61 & $0.00^{* * *}$ & 2.81298 \\
\hline COSMOP & -0.8872 & 0.5399329 & -1.64 & 0.103 & -0.7868346 \\
\hline $\begin{array}{l}\text { Obs. summary:46left-cen } \\
\text { 104uncensored observati } \\
\text { Oright-censored observati }\end{array}$ & servations at $\mathrm{DV}<=$ & & & & \\
\hline
\end{tabular}

Source: Own estimation result, $* * *, * *$ represents $1 \%$, and $5 \%$ level of significance respectively.

\section{Conclusions and Policy Implications}

\subsection{Conclusions}

This paper has provided estimates of adoption rates and the determinants of adoption for improved highland maize verities in Toke Kutaye District, Oromia regional state, Ethiopia.The level of adoption observed is an indication of the existence of substantial potential to improve smallholders' productivity with minimum cost compared to the development and introduction of new technologies. As repeatedly stated improved highland maize varieties production is important in solving food security and poverty problems in agriculturebased economies. Furthermore, the study has shown the exposure to improved highland maize varieties and their adoption by farmers is influenced by farm size, household income, access to credit, contact with extension agentsand participation in farmer's training. Similarly, this study argues thatthe role of institutional support provided to the farmers, such microfinance service, research and technology transfer was not to the expected level. The findings are indicative of relatively large demand for improved agricultural technology in the study area suggesting that there is scope for increasing their adoption intensity.

\subsection{Policy Implications}

The adoption and intensity of use of improved highland maize varieties affected by several household personal, demographic and socio-economic factors together with positively and significantly influenced study variables which canconsequently affect theproduction and productivity of smallholder farmers. Therefore, policy makers and government intervention related with agricultural technology transfer should take significantly influenced variables into consideration.

\section{References}

[1] Abera, H.B, (2008). "Adoption of Improved teff and Wheat Production Technologies in Crop-Livestock Mixed Systems in Northern Shewa Zones of Ethiopia". Unpublished PhDDissertation, university of Pretoria. about.com/od/global problems and issues/a/green revolution.htm. Accessed 5 May 2016.

[2] African Biotechnology stakeholders Forum (ABSF),
(2010)."Maize Production and Improvement in Sub-Saharan Africa", first published by the African Biotechnology Nairobi, Kenya".Assessment of Evidence. EPDT Discussion Paper No. 87, International Food Policy Research Authorization of a New Plant Biotechnology Derived Trait. A Consultancy Study for Crop Life.

[3] Bandiera, O., and I.Rasul, (2006)."Social Networks and Technology Adoption in Northern Mozambique". nb(2006).

[4] Briney, A., (2015)."History and Development of Green Revolution". Available at: http://geography.Contemporary Issues in Technology and Teacher Education [Online serial] 2(2). Retrieved from Contemporary Issues in Technology and Teacher Education [Online serial] 2(2). Retrieved from Cornell University, Ithaca.

[5] CSA (Central Statistical Agency), (2011). "National Statistics report abstract". Addis Ababa, Ethiopia.

[6] Demissew et al., (2013).“Farmers' Perceptions of Maize Production Systems and Breeding Priorities, and Their Implications for the Adoption of New Varieties in Selected Areas of the Highland Agro-Ecology of Ethiopia", Journal of Agricultural Science; Vol. 5, No. 11; 2013: ISSN 1916-9752 E-ISSN 1916-9760: Published by Canadian Center of Science and Education, Canada.

[7] Dethier, J.-J., and A. Effenberger, (2012).“Agriculture and Development": A Brief Review of the Dibba, L., S.C.

[8] Fialor, A. Diagne, and F. Nimoh, (2012)."The Impact of NERICA Adoption on educational-Technology".Farmers in Mozambique. Staff Papers, Department of Applied Economics and Management, Getting-a-Biotech-Crop-to-Market-PhillipsMcDougall-Study.pdf.http://www.citejournal.org/volume2/issue-2-02/general/the-path-to-teacher-leadershipineducationalTechnology. http://www.citejournal.org/volume2/issue-2-02/ general/the- path-to-teacher- leadership-inin the Soybean Complex. Agribusiness 16 (1): 33-55.Institute, Washington, DC.

[9] Feder, G.R., Just R.E. \& Zilberman, D., (1985).“Adoption of Agricultural innovations in developing countries": A survey data. Economic Development and Cultural Change, 33:255298.

[10] Maddala, G.S., (1992)."Introduction to Econometrics". Second Edition, New York”. Macmillan Publishing Company.

[11] Mcdonald, J.F., and R.A. Moffit, (1980).“The uses of Tobit Analysis". Review of Economics and Statistics 62(2):318-321.

[12] Moshini, G., H.Lapan, and A. Sobolevsky, (2000).“Roundup Ready Soybeans and Welfare Effects".nb(2000). 
[13] Mosisa et al.,(2012)."Status and future direction of maize research and production in Ethiopia". Global Climate Change and Food Security through Innovative Maize Research". Proceedings of the 3rd National Maize Workshop of Ethiopia. 18-20 April 2011, Addis Ababa, Ethiopia. pp. 17-23.

[14] Nkonya, E., T. Schroeder and D. Norman, (1997).“Factors affecting adoption of improved maize seed and fertilizer in Northern Tanzania". Journal of Agricultural Economics, 4(1): $1-12$.

[15] Phillips-McDougall., (2011).“The Cost and Time Involved In The Discovery, Development and Presented at Dialogue on Promoting Agricultural Growth in Mozambique". International Food Policy Research Institute. Food Security report 4 (2): 253-265.

[16] Rogers, E.M., (2003). "Diffusion of Innovations". 5th New York: The Free Press.

[17] Sherry, L., and D. Gibson., (2002). "The Path to Teacher Leadership in Educational Technology Adoption".The Economic Journal 116 (514): 869-902.
[18] Twumasi-Afriyie, S., Zelleke, H., Yihun, K., Assefa, B., \& Tariku, S., (2002)."Development and Improvement of Highland Maize in Ethiopia". In M. Nigusse \& D. Tanner (Eds.). Proceedings of the Second National Maize Workshop of Ethiopia, 12-16 November 2001. Addis Ababa, Ethiopia (pp. 31-38).

[19] Uaiene, R.N., (2011). "Determinants of Agricultural New Technology Adoption and Adoption Intensity". Paper Presented at Dialogue on Promoting Agricultural Growth in Mozambique.” International Food Policy Research Institute, July, 2011.

[20] World Bank (2013). "World Annual Country's Development Report". Ethiopia a tag lance http://devdata.worldbank.org/AAG/eth_aag.pdf

[21] Zavale, H., E. Mabaya, and R. Christy., (2005).“Adoption of Improved Maize Seed by Smallholder farmers”. $\mathrm{Nb}(2005)$. 